\title{
GENDER INEQUALITY AND FEMALE SPORTS PARTICIPATION IN TURKEY
}

\author{
Meltem Ince Yenilmez \\ Department of Economics, Yasar University, Izmir, Turkey \\ Address for correspondence: \\ Meltem Ince Yenilmez \\ Yasar University, Department of Economics \\ Üniversite Cad. Ağaçlı Yol No: 35-37 \\ Bornova, IZMiR \\ E-mail: meltem.ince@yasar.edu.tr
}

\begin{abstract}
Ahstragt Research Questions: Discrimination remains a sore point for women in Turkish sports. This has subsequently hindered women from participating or building thriving careers in sports in Turkey. Many women are discouraged from taking part in professional sports due to the perceptions existing around such activities. Therefore, the Turkish female sports sector is growing at a very sluggish pace. The present study evaluates Turkish women's roles regarding connections between sports and politics to revolutionize the country. This assessment is vital to understand the barriers to Turkish women's sports participation and what can be done to encourage more women to invest in professional sports.

Research Methods: The present study provides an in-depth view of the limiting factors hindering women from developing thriving professional Turkish sports careers. The research utilizes a semi-structured questionnaire to establish data from about 162 female participants (amateur and professional sportswomen) in different cities across the country.

Results and Findings: The present study highlights that unequal salaries, unavailability of sports facilities for women, media misrepresentation, and pressures from the family, are some of the factors limiting the participation of females in Turkish sports. Inferences: The study provides insights on the vitality of sports programs and physical activities, everyone, including females. The study further emphasizes the need to create enabling environments that will foster female participation in Turkey's sports.
\end{abstract}

Key Worlds sports, women, female athletes, gender discrimination, wage inequality, media

\section{Introduction}

Sports have always been more than a social activity; it is considered one of the most valuable social tools for connecting individuals across the local and global landscape (Velazquez, 2017). The general understanding of sports has always been positive and regarded as human-friendly engagement in day to day life (Jabeen, Marwar, Khan, Ali, 2017). On a personal scene, sports can equally play a psychological, social, emotional, mental, and physical developmental role in participants' lives (Khan, Jamil, Khan, Kareem, Imran, 2012). Therefore, sports' importance is broad and diverse, encompassing a role in individual economic value, health fitness, and promoting peacebuilding and community regeneration (Gorman, Butler, Rauh, Kiesel, Plisky, 2012; UNESCO, 2015). 
Nevertheless, sports participation has always been seen as positive in promoting social capabilities and academic responsibilities. Research further proves that sports participation is valuable to developing particular attributes, including the sense of well-being, sound health, getting entertainment, and weight control (Jabeen et al., 2017). It can further be considered a part of the local culture, connecting the young and old while creating opportunities for young people to pursue a potential that is non-academic (Jaenes, 2017). Therefore, it can be seen as a tool for promoting gender equality and social inclusion for women and girls (Wangari, Kimani, Wango, 2017).

However, the reality is quite different, especially for women in sports. Many women have been exposed to discrimination and social exclusion, for example, sexism, gender inequality, and homophobia (Cleland, 2014; Wangari et al., 2017). Many sports scholars have investigated this "dark side" of sports revealing that sports have in the past reinforced damaging and dangerous social patters such as excessive violence, homophobia, gender inequality, and racism (LaVoi, Kane, 2011)

There are countries where women are not allowed to participate in professional sports. In contrast, some other states allow participation but with severe discrimination levels in diverse areas, including the kind of picture depicted by the media (Fahmy, 2011; Hardin, Croston, 2012).

Diverse schools of thought have carried out studies about the reasons that promote female involvement in sports and physical activities in several groups. However, a handful of literature has actually discussed the problems that influence female participation in sporting activities (Ahmad, 2015; Ballantyne, Kayser, Grootegoed, 2012).

In times past, sports were considered a male-dominated world, and women were considered outsiders in the game (Wangari et al., 2017). This means that the world of sports has always been perceived as more masculine than feminine. These views are also held by diverse countries globally (Hardin, Croston, 2012; Feldman, Barnette, Shrier, Abenhaim, 2003; FIFA, 2015; Saavedra, Martha, 2010). Initially, women were perceived to be the other sex; they were not the leading insiders and were mainly considered to be latecomers or newbies who were only permitted to participate in friendly games or sports (FIFA, 2015; Pfister, Hacısoftaoğlu, 2016; Gorman et al., 2012).

Furthermore, the popular conception, equally held by women, is that the less strenuous activities are meant for women. At the same time, men can participate in a wide variety of activities (Ruseski, Humphreys, Hallmann, 2011; FIFA, 2015). For instance, there is a perception that football is a sports activity suitable to men alone, while women can take part in gymnastics (Fahmy, 2011; FIFA, 2015). Such perceptions have been around for decades and are not only gender convictions and patriarchal ideologies, but further supported by science (Feldman et al., 2003). In 1953, Buytendijk, a renowned philosopher, shed insights on female football, denoting it as a game for the full expressions of masculinity, especially as men have the physical constitution for such activities. He further stated that women have never been successfully driven to engage in the game. (Buytendijk,1953). Many other studies also support such views, leading to a higher volume of women in low and moderate sports activities. In contrast, a higher number of men are found in activities with higher intensity (Jabeen et al., 2017).

Furthermore, a study concerning women's football in 2014 also shows a poor perception that women should not be allowed to feature in sports activities such as football (FIFA, 2015). Such perceptions are also found in Turkey. Even as the creation of the Modern Turkish Republic, after the dissolution of the Ottoman Empire, in 1923 brought about the development of laws and regulations on the grounds of inheritance issues, gender equality in divorce, rights to vote, female participation in politics, and secularization, gender inequality is still an issue in the country (Koca, Hacısoftaoğlu, 2010; Gorman et al., 2012). 


\section{Turkish Sports and The Adverse Effects of Gender Discrimination}

Turkey's geographic position is a very distinctive one, especially when bearing in mind the common history shared with many other Islamic countries within the region. Nevertheless, the country remains unique and may never be effectively compared to these other countries because Turkey has made attempts in the past to adopt a secular system to become a genuinely contemporary society. One such instance, which shows this uniqueness, is policies concerning women's liberation (Koca, Hacısoftaoğlu, 2010). However, several researches also argue that patriarchy is still as dominant as it is in other Islamic countries in the region, even as the country stands out. Therefore, such ideologies are adversely impacting the perceptions and acceptance of sportswomen in the country (TUIK, 2012b).

These views are deeply entrenched, especially when ones bear in mind that sports are perceived as masculine and seen to be synonymous with aggression and force whereas, most people perceive feminine activities as those concocted with elegance, gentleness, passivity, and weakness (Pavlidis, Fullagar, 2016; Nogueira, Molinero, Salguero del Valle, Lucidi, Marquez, 2017).

Besides, women who participate in sporting activities seen as masculine in nature must contend with the restrictions and marginalization, including labeling individual sports as more appropriate for women and others as not fitting for typical female behavior (Nogueira et al., 2017).

However, in recent years there has been a significant increase in the number of women in Turkish professional sports and international sports competitions, including receiving medals for international sports competitions (Koca, Hacısoftaoğlu, 2011). The evolving roles of women, their behavioral patterns, and activities have also provided Turkish women with new opportunities and play a significant role in female representation in Turkey's professional sports (Koca, Hacisftaoglu, 2010). In 2010 alone, more women were competing in volleyball $(10,599)$, taekwondo $(9,353)$, basketball $(4,714)$, karate $(4,101)$, swimming $(1,952)$, kickboxing $(1,924)$, handball $(1,859)$ and judo $(1,543)$ (Koca and Hacisftaoglu, 2010).

There is no doubt that a country's evolution can be depicted by women's involvement in government job positions alongside their heightened sports participation (Nogueira et al., 2017; Ponseti, Borrás, Cantallops, GarcíaMas, 2017; Wangari et al., 2017). The issues of gender equality in the sports environment are a severe issue as research has equally shown that when there are equal opportunities for women and men, it provides personal and organizational, societal, and national benefits (Spaaji, Anderson, 2012). Therefore, when gender inequality problems abound, it limits a country's growth in social and economic aspects, which means the gender equality gap in Turkey must be filled. The sports sector is a principal area requiring significant attention. Upholding gender equality's tenets provide immense benefits to men and women alike as improving diversity, especially in Turkish sports, will further help attract the international sporting community (Bruce, 2015; Sailors, Teetzel, Weaving, 2012).

When gender equality tenets are implemented, females will be motivated to build thriving and long-term careers in sports (Burton, 2015; Pavlidis, Fullagar, 2016; Jacobs, 2017; Walker, Bopp, 2010). However, as long as social and cultural limitations, traditionalism alongside familial pressures, poverty, low literacy levels, religious rules, and unavailability of sports facilities and equipment continue existing, it discourages females from seeking a career in sports and as such as the present climate in Turkey (Koca, Hacısoftaoğlu, 2010; Öztürk, Koca, 2019). Further studies by the Hacettepe University Institute of Population Studies (2019) show that over 76.5 percent of women and girls over the age of 12 do not participate adequately in physical activities. Furthermore, their levels of participation are almost insignificant when compared to the involvement of men and boys in Turkey in physical 
activities (Ministry of Health, 2014; Öztürk, Koca, 2019). Studies have also shown that participation in physical activity can only be promoted through individual, environmental, socio-cultural, and psychological factors (Brien, Lloyd, Riot, 2017; Zhang, Solmon, Gao, Kosma, 2012). Therefore, the present study will provide insights into how socioeconomic factors, limited resources, media misrepresentation, and wage inequality affect women's Turkish sports participation.

\section{Gender Inequality and Segregation}

Over the years, the emergence of women into professional sports or even physical activity has met with mixed reactions across the globe. These reactions have brought about diverse discriminatory issues that are deeply entrenched in the underlying gender gap. The Liberal Feminism theory advanced by Mary Wallstone, John Stuart Mill, and Harriet Taylor, as expressed in Wangari et al. (2017), equally evaluated these reactions. With a focus on stereotypes, gender roles, power and oppression, sex and gender, objectification, structural and economic inequality, the Liberal Feminist theorists stated that the family mostly impacts the differences seen in female sport participation, school, and media (Story, Markula, 2017). According to the Liberal Feminists, prejudice, division, and social discrimination primarily begins from birth. It may continue for life without adequate intervention. Therefore, the discriminatory practices hindering women from equal access to various professional sporting activities are enormous.

Consequently, women do not have many opportunities for competition compared to their male counterparts. Liberal Feminist theorists equally hold the positions that the number of tournaments and leagues available to women at the local, national, and international levels is insignificant compared to the numerous opportunities available to their male counterparts. Further, studies by Mean (2014), show that the media trivializes women's tournament and leagues. Even as it is widely acknowledged that sporting activities can lead to more robust health and mental development, the level of perceptions meted to women in sports is shocking (Mean, 2014). Kian, Bernstein, McGuire (2013) further identifies the lack of adequate coverage for female athletes alongside the growing fact that online media sports workers contribute to the "problematic" reproduction of traditionally gendered discourses, including asymmetry in production values and provision that frames women as feminized and outside the main category of sport, reproducing women's sport as substantively less action-packed and newsworthy than men's sport. Women sports fans as less sophisticated than men" (in page 339). Many ideologies of women's positions depict them as being responsible for household chores without the responsibility of bringing home financial income (Wangari et al., 2017). Therefore, the more significant majority draws invisible rules in the stand that terms sport "as a masculinizing activity" (Knoppers, McDonald, 2010) and identifies media sport "as a site of culture thoroughly saturated in ideologies that gives men the privilege while sidelining women, whether they appear as subjects of coverage, audience members or journalists (Bruce, 2013). Furthermore, in the past, the main ideologies by the media limiting the growth of women sports participation were that women's sports (i) yielded lower broadcast production values; (ii) women's sportswomen deserved to be called by their first names and were covered as girls and women without emphasizing their professional achievements (Jones, 2013); (iii) women's sports activities were highlighted based on non-sports related aspects such as their appearance, personality, and family; (iv) women's sports were gendermarked, and for instance, viewed as "the girl's team" or "women's events, while male sports activities were seen as the main events (Jones, 2013); (v) statements flattering female athletes as not trying hard enough and therefore, viewing their actions as inferior to their male athletes. 
However, the present climate is even worse as there exist two persistent perceptions (Bruce, 2015). First, the current realities consistently emphasize the message that sportswomen do not matter. This is further emphasized by Bruce, Scott-Chapman (2010). Their studies highlighted that women's sport receives only 11 percent coverage all over the world. Secondly, the present view sexualizes women's sports, as more sportswomen appear in provocative attire and are featured in magazines interpreted as sexualization or even "soft porno" (Kane, Alavi, Labianca, Borgatti, 2014).

Apart from these ideologies, women also experience cultural and religious limitations. For example, Brunei and Qatar did not allow women to participate professionally as Football players until the 2012 Olympics because of Islamic dress codes (Wangari et al., 2017).

In the case of Turkey, the country has been in the Olympics since 1932. However, their iconic appearance at the Olympics was made in 2012 when 50 percent of the Olympics participants were women (Leigh, 2012). Nevertheless, it is quite clear that Turkish women gained access to professional sports in the 1950s. However, too much gender segregation limited the progress the country attempted making with regards to gender equality. However, many were either not paid or underpaid for their contributions (Ince Yenilmez, Çelik, 2020). It was the standard practice to hinder females from participating in "male events" and vice versa (Leigh, 2012). Furthermore, the Liberal Feminism Theory also brings to light the Underrepresentation of women in decision making positions in sports, especially in management and coaching areas. These theories were prescribed by Knoppers, 1994, and expressed in Wangari et al. (2017). It is the perception that men have more capabilities for making decisions than women and are best suited for those provisions. Therefore, the Liberal Feminism Theory brings to light these discrepancies that have led to more men in critical decision-making positions in governing and administrative functions than women, especially in sports organizations. These have led to lower allocations of funds and resources to women sports organizations resulting in unequal wages and awards.

Nevertheless, this theory does not provide a complete view of the extent of discrimination. The approach fails to highlight the difference between women and instead depicts them as a homogenous group. Therefore, the theory fails to show their differential interests and religion, family, work, and educational differences, which also affects the status of women in society (Wagner, 2016).

A different theory put in place by Bruce, Hovden, Markula (2010) shows that the media also plays a part in discrimination. The media does not fully cover women's sports than men's sports (Moradi, Yoder, 2011). Furthermore, cases where the media covers these events, these women are usually sexualized, trivialized, and marginalized; therefore, distorting their correct roles and achievements in the world of sports.

Because the media represents the male athletes by their professional achievements and the females by their personal attributes, gender inequality issues keep rising (Aslan, Koca, 2007; Jones, 2013). Therefore, as long as sportswomen are seen based on their personal attributes, it only paints the picture that their achievements are not newsworthy (Jones, 2013).

\section{Turkey's socio-cullure structure}

Turkish women's discrimination in sports is not based alone on media representation but on many other social, historical, and cultural ideologies. Therefore, it is vital to look at these contextually, especially the events following the establishment of the Modern Turkish Republic and dissolving the Ottoman Empire. There are apparent incidents that show that Turkey is making progress towards reforming its policies to promote gender equality in education, 
employment, and political life (Acar, Altunok, 2013; Koca, Hacısoftaoğlu, 2011). The $20^{\text {th }}$ Century began with Turkey giving social, legal, and political rights to females (Müftüler-Baç, 2012). On those grounds, several past studies have documented this move to fully ascertain its effectiveness (Acar, Altunok, 2013; Toksöz, 2012). However, other policies enacted in 2015, taking the country in the backward direction as conversation and traditionalism, are once more the people's main perceptions. Therefore, women are thus seen first as mothers and wives. So, the traditions and customs are taking the central state in the present era (Sumer, Eslen-Ziya, 2015). This further heightens the contraindications, traditionalism, and restrictions, alongside inadequate sports and recreational centers, low education labors, and family responsibilities, all of which are discouraging more women from becoming active sportswomen in the country (Koca, Hacısoftaoğlu, 2011).

\section{Problems hindering the growth of female participation in Turkish sports}

Past works of literature highlight that family pressures, overcrowding, lack of time, lack of companionship, financial issues, and distance of sports facilities limit female participation in sports activities (Stanis, Schneider, Pereira, 2010; Scott, Mowen, 2010: Kara, Demirci, 2010). Some research has further grouped these challenges into physical, economic, and socio-cultural issues (FIFA, 2015; Wangari et al., 2017). Other works also denote the lack of energy or time as one of the most critical challenges preventing female participation in sports (Story, Markula, 2017; Wangari et al., 2017). Furthermore, some works of literature have also highlighted that income level might be one of the factors limiting women's growth in sports because income is vital to gaining more significant role in sports activities than age, gender, educational level, and race (Johnson, Salzberg, Stevenson, 2011).

\section{Methodology}

\section{Participants}

The researcher distributed questionnaires to professional, amateur, and recreational female athletes over age 21. The questionnaire was dispersed to online groups, groups, universities, and public facilities were female athletes commune. In the end, over 162 females, including professionals, amateurs, and recreational sportswomen, participated in the study. Therefore, the researcher collected demographics alongside other sports-related information.

\section{Instrument}

The research follows a descriptive methodology using an 18-question semi-structured questionnaire specifically adapted for the present study. The self-administered questionnaire was prepared following the guidance from experts in sociology and Physical Education alongside other works of literature (Wilson, Spink, 2006) to assess the variables used in the present study adequately. Variables include wage inequality, sexual harassment, unavailability of sports facilities and equipment, family influence, and media representation. Sub-dimensions follow the Likert Scale ratings from 1 (Disagree) to 5 (Highly Agree).

\section{Hypothesis}

Through an in-depth study of previous works of literature, alongside the aim of the current study, the researcher proposes: 
Hypothesis $2(\mathrm{H} 2)$ : Wage inequality, as regards their male colleagues, discourages active female participation in sports.

Hypothesis $3(\mathrm{H} 3)$ : Media misrepresentation adversely impacts on female involvement in Turkish sports.

Hypothesis $4(\mathrm{H} 4)$ : Unavailability of facilities and equipment dedicated to female teams negatively affects female participation in Turkish sports.

Hypothesis $5(\mathrm{H} 5)$ : High prevalence of sexual harassment hinders more women from participating in sporting activities in Turkey.

\section{Data Analysis}

Data from the questionnaire were evaluated using IBM SPSS Statistics to visualize the respondent's choices using descriptive methodologies, including the Chi-Square and Friedman tests on the grounds of the present study's hypothesis and objectives.

\section{Results}

Majority of respondents attained College (27.12\%), as shown in Table 1. Table 1 also indicates that over $49.13 \%$ of respondents were between 20 and 30 years, while around $82.67 \%$ were employed in full-time positions. Over $68.77 \%$ of respondents also participated in sports activities. In comparison, $58.45 \%$ had children, and over $60.56 \%$ had participated in sports events within the last few years (see Table 1 for details).

Table 1. Demographic data of participants

\begin{tabular}{lccc}
\hline \multicolumn{1}{c}{ Variables } & Groups & $\mathrm{N}$ & Percent \\
\hline \multirow{3}{*}{ Education Level } & Elementary School & 22 & 14.71 \\
& Junior High School & 29 & 20.43 \\
& Senior High School & 37 & 22.83 \\
& College & 34 & 27.12 \\
& Graduate School & 20 & 14.91 \\
\hline \multirow{3}{*}{ Age } & $20-30$ & 65 & 49.13 \\
& $31-40$ & 56 & 37.86 \\
& $41-50$ & 17 & 10.58 \\
\multirow{2}{*}{ Full-time job } & $51-60$ & 4 & 2.14 \\
\multirow{2}{*}{ Have kids } & $>61$ years old & 0 & 0.00 \\
\hline \multirow{2}{*}{ Married Status } & Yes & 115 & 82.67 \\
& No & 27 & 17.33 \\
\hline \multirow{2}{*}{ Participated in the sports club } & Yes & 89 & 58.45 \\
& No & 53 & 41.55 \\
\hline
\end{tabular}

Analysis of the data collated via the questionnaire regarding the study's hypothesis emphasizes the five variables as the main impeding factors limiting the participation of Turkish women in sports. These variables are 
organized according to their effectiveness and vitality with regards to promoting the growth of women's involvement in Turkish sports, and their preference as denoted by the Friedman test is indicated below:

1. Family influence can motivate girls and women to participate actively in Turkish sports ( $x=4.39$ of 5 ).

2. Wage Inequality, in regards to their male colleagues, discourages active female participation in sports $(x=4.31$ of 5$)$.

3. Media misrepresentation adversely impacts on female involvement in Turkish sports ( $X=4.16$ of 5 ).

4. The unavailability of facilities and equipment dedicated to female teams negatively affects female participation in Turkish sports ( $X=4.12$ of 5 ).

5. High prevalence of sexual harassment hinders more women from participating in sporting activities in Turkey $(x=3.89$ of 5 .)

Table 2. Percentile distribution of participant's choices in completing the questionnaire

\begin{tabular}{|c|c|c|c|c|c|c|}
\hline & & Very High & High & Med & Low & Very low \\
\hline \multicolumn{7}{|c|}{ A. Family Influence } \\
\hline 1. & My family feels that sports participation is a waste of time & 78 & 12 & 6 & 2 & 2 \\
\hline 2. & My family supports my sport's ambition & 69 & 21 & 5 & 3 & 2 \\
\hline 3. & My family encourages me as a result of the vitality of sports & 57 & 25 & 11 & 6 & 1 \\
\hline 4. & My family's wishes do not matter & 8 & 11 & 27 & 23 & 31 \\
\hline \multicolumn{7}{|c|}{ B. Wage inequality } \\
\hline & The pay is lower than male counterparts & 61 & 24 & 11 & 3 & 1 \\
\hline & I need double jobs to create a substantial income & 43 & 31 & 22 & 4 & 0 \\
\hline 7. & The awards and sponsorships for women are very low & 52 & 39 & 7 & 2 & 0 \\
\hline
\end{tabular}

C. Availability of Standard Sports Facility and Equipment

\begin{tabular}{rllllll}
\hline 8. & Standard facilities encourage female participation & 60 & 19 & 13 & 5 & 3 \\
9. & Equipment are available for female sports activities & 68 & 18 & 7 & 4 & 2 \\
10. & We can only use the sports facilities if the men are not using them & 62 & 21 & 12 & 4 & 1 \\
11. & Lack of proper methods for talent identification in athletics & 38 & 30 & 28 & 1 & 3 \\
\hline
\end{tabular}

\begin{tabular}{|c|c|c|c|c|c|c|}
\hline \multicolumn{7}{|c|}{ D. Media misrepresentation } \\
\hline 12. & Limited exposure to mainstream media coverage & 64 & 19 & 8 & 4 & 5 \\
\hline 13. & The media fails to help attract the right sponsors & 57 & 28 & 11 & 3 & 1 \\
\hline 14. & I am objectified for my body instead of my abilities & 53 & 25 & 16 & 4 & 2 \\
\hline 15. & Objectified for my body rather than my abilities & 42 & 36 & 15 & 7 & 0 \\
\hline \multicolumn{7}{|c|}{ E. Sexual Harassment } \\
\hline 16. & Judged for my dresses/sporting attires & 38 & 24 & 27 & 7 & 4 \\
\hline 17. & I have to make to with hostile or offensive statements from other people & 61 & 23 & 9 & 5 & 2 \\
\hline 18. & I receive requests for sexual favors and unwelcome advances & 57 & 26 & 10 & 4 & 3 \\
\hline
\end{tabular}

Table 2 depicts wage inequality, family influence, unavailability of facilities and sports equipment, media representation, and sexual harassment as the critical variables limiting Turkish women's sports growth. 
Tahle 3. Results of Statistical Analysis

\begin{tabular}{llllll}
\hline \multicolumn{1}{c}{ Hypothesis } & $X^{2}$ & $d f$ & $P$ & Accept & Decline \\
\hline 1. & Family influence can encourage females to take part in active sporting activities & 18.715 & 4 & 0.002 & Yes \\
\hline $\begin{array}{l}\text { 2. } \\
\quad \begin{array}{l}\text { Wage inequality compared to their male counterparts can discourage females from } \\
\text { taking part actively }\end{array}\end{array}$ & 53.672 & 6 & 0.001 & Yes \\
\hline 3. & Misrepresentation by the media negatively affects women in sports & 31.769 & 3 & 0.001 & Yes \\
\hline $\begin{array}{l}\text { 4. } \\
\quad\end{array}$ wack of facilities and equipment specially installed for female teams negatively affects & 22.147 & 6 & 0.001 & Yes \\
\hline 5. & High levels of sexual harassment negatively affect women in sports & 71.916 & 5 & 0.001 & Yes \\
\hline
\end{tabular}

Table 3 outlines the results from the test for the hypothesis. According to the table, a vast number of hypothesis exists within the significance of 0.001 . Further analysis using the $X^{2}$ test, five factors are acknowledged, for it was recognized that five factors are limiting the growth of female participation in Turkish sports. From results, wage inequality appears to be the most significant factor discouraging women from participating and building great sports careers. Subsequently, the unavailability of facilities and sports equipment for women is also a great challenge hindering female sports participation, alongside significant sexual harassment incidents.

\section{Discussion}

As outlined from the study results, five vital variables - sexual harassment, wage inequality, funding limitations, media misrepresentation, and family influence - are responsible for impairing the future of female participation in Turkish sports.

\section{Influence of parents}

Previous studies confirm the findings that family influence is significant by Bibi, Khan, Khan, (2016) on the reviews of parental problems on sports participation in Pakistan. Pelak (2005) also asserted that parental involvement could become a critical motivational factor in sports participation. Therefore, when parents fail to show their interests, it might discourage the child from following that path (Taylor, Schweichler, Jorgensen, McKown, Teresak, 2014). These parental influences are mainly in attitude, motivation, and finance, which are essential and influential tools for females in sports. A study by Maclntosh, Nicol (2012) has equally shown that parents provide a vital support system that can aid their children in participating in sporting activities, especially seeking professional paths in that regard. The present study shows that the almost lack of parental influence affects or inhibits women's growth in professional sports in Turkey. This is also in line with the survey by Marwat, Zia-ul-Islam, Waseem, Khattak, BiBi (2014) that sports participation among female folk in Muslim countries is relatively weak. Again, Kanters, Bocarro, Casper (2015) also state that parents may prevent their female wards from participating in professional sports without a clear perception of the fruitful outcomes of professional sports.

\section{Wage disparity}

One of the great gender issues affecting Turkey alongside many other countries globally is the lingering gap in wages earned for males and women in similar jobs (Tansel, Dalgic, Guven, 2014). This enormous gap is also visible 
in the sports sector and especially observed in these research results. As also confirmed from previous literature works, many male athletes earn twice as much as their female colleagues. These figures climb as far as ten times (Forbes, 2016; Monster Salary Index, 2017). In the present study, many participants highlighted that their insufficient income from sports is why they seek other full or part-time employment. However, previous literature works have highlighted that these gaps are further fueled by the fact that sportspeople receive greater media coverage, which in turn fosters the environment for endorsements and sponsorships (Moradi, Yoder, 2011).

Further analysis by Kagnicioglu (2012) observed that Turkey's lingering patriarchal ideologies play a huge role in women being paid less than men in similar positions. There is a lingering perception that women cannot put in the hard work that their male colleagues boast off. Therefore, the general perception is that women deserve a lesser wage than their male counterparts (Kagnicioglu, 2017).

\section{Sexual harassment}

From the present study results, sportswomen in Turkey deal with an untold amount of sexual harassment, and in many cases, violence. According to Westcott, Foley-Fellow (2018), these high levels of sexual harassment are witnessed by most Turkish women in paid employment positions in the Turkish labor market. Furthermore, in 2017, over 409 women were killed, and 387 children were abused primarily due to their gender (Hurriyet Daily News, 2018). Therefore, sexual harassment and the high prevalence of violence are the biggest issues discouraging females from seeking great employment positions in the country. Bibi et al. (2016) further state that societal restrictions and violence exist across all aspects of these women's lives. According to the study, fear and violence are existing social control mechanisms used in limiting women from engaging in outdoor activities, such as sports activities. In a similar study, Khan et al. (2012) further stated that the fear of violence, fear of homelessness, and fear of being seen as engaging in immoral social behavior are factors limiting women's participation, especially in sports activities.

\section{Misrepresentation of female sports by the Media}

The media plays a vital role in the growth of any country's sports climate, and Turkey is not left out. According to Lin, Liu, Lee, Tsai, Chen, Lee (2012), the growth of any sports activity, such as Turkish women's sports, is dependent on the media's mode of representing these activities and teams. Therefore, when female athletes are trivialized, depicted as sexual objects, or streamed on the grounds of their personal attributes instead of their professional achievements, the result is stunted growth. This is further confirmed by Trolan (2013), who observed that when the media trivializes, sexualizes, underrepresents, or heterosexualizes females' bodies, the media limits the growth of women's professional sports careers. Furthermore, Trolan (2013) postulates that such continuous image only increases the perceptions that men are better suited to sporting activities and, therefore, superior to women athletes. Turkish media is no exception as traditional perceptions linger in the media's handling of women's sports activities (Arslan, Koca, 2007) because traditionally, women are perceived as homemakers, dependent and framed as pliable. Their participation in sports is underplayed. Many Turkish media outlets trivialize sportswomen based on their roles as wives, mothers, and grandmothers or worse as sex objects (Ayvazoğlu, 2017).

Moran (2014) also discovered that the coverage of mass media for female sports is limited. Most times, the news articles published in Turkey are for actions they took that the public considers terrible. Usually, these connate to the preferred dressings for women. According to Moran (2014), Turkey's general society continues to hold the view that women must wear the full hijab, long dress, and full sleeves in all activities. It can be scorching 
and uncomfortable for the sportswomen to do so, which has become severe barriers. Another study confirms that female athletes are usually talked about concerning their personal lives and physical appearance rather than another detail (Huffington post, 2016).

Many other findings also show that religion, culture, and mass media may together have a significant influence on the growth of women in professional sports in Muslim countries like Turkey (Tekin, 2010: Fitzgibbons, 2015; Khalaf, 2014). The media also impacts on attracting the right sponsors for women's sports activities. Without comprehensive support from the economic situation in women's sports will be bleak. It is quite apparent that when the media ignores particular sporting activities, fewer sponsors will invest in those areas (Asayesh, Karkon, Karkon, Shabani, 2013).)

\section{Inadequate sports facilities and equipment}

According to respondents in the present study, the unavailability of sports facilities and women's equipment is a considerable limitation. Previous studies by Saavedra, Martha (2010) highlight that the few available facilities and equipment are only available to women on occasions when males do not require them. Therefore, such incidents will further limit female participation in sports in the country. These views are supported by Huang, Liu, Chang, Hsieh, Lu (2019), which stated that when community sports facilities are provided, it can encourage the public to participate in sports activities. Chien (2013) further asserts this theory and also argued that the right sports environment promotes active participation. Furthermore, the researcher equally stated that provisions while bearing in mind factors such as accessibility, extensity, safety, support, and aesthetics are crucial to providing the right motivation for improved participation. A study by Asayesh, Karkon, Karkon, Shabani (2013) equally confirms that it can discourage the growth of such sports when there is limited access to facilities and equipment.

\section{Conclusion}

The current study explores the different challenges faced by Turkish women in sports. Among the findings from the study include media misrepresentation, sexual harassment, parental influence, wage inequality, and unavailability of sports equipment and facilities. The course recognizes that these constraints can become opportunities for improvement, which will otherwise lead to an increase in Turkish women's participation in sports. Studies also reveal that despite the changes regarding women's rights implemented in the 1990s, Turkey still has a long way to completely change the role and perceptions of women in society. This is because the levels of discrimination, wage inequality, and unavailability of sports facilities are still considered restrictions that discourage the growth of women's sports in the country.

A limitation of this study was the lack of resources to adequately distribute questionnaires to diverse females in sports across Turkey. The study was also unable to assess the different sporting levels of the participants properly. The researcher acknowledges that this bias may hinder the accuracy of the data presented. However, the study did not collect data from a single locality and attempted to maintain randomness. The present study is an important finding because it explicitly limits female participation in Turkish sports. No study has evaluated the restrictions discussed in this research paper at the time of investigations. The study's findings also highlight areas that can be improved to transform the future of women's sport in Turkey.

Based on the present study's findings, the ensuing recommendations suggest ways to drive up female participation in Turkish sports and further help grow the sports climate in Turkey. First, there is a need to create 
detailed policies and execution plans that will foster gender equality within sports institutions in the country. Such an enabling environment should also make provisions for women's coaching opportunities and eliminate sexist gender stereotypes in Turkish sports. Such policies and plans can help create a positive environment that increases women's participation in Turkish sports. Secondly, there should be dedicated sports and physical activity programs created for females at local and regional levels to help boost awareness about sports' vitality for both men and women. Thirdly, provisions should be made for rewards and incentives to encourage more females to invest in building their sports careers. There is also a need for awareness campaigns to help spread the positive impact of sport on women's health to all local communities and regions in the community. Concurrently, there is a need to implement policies that will obligate the media to cover female sports activities without trivializing or sexualizing female sports. Finally, it is extremely vital to promote gender equality in sports because it is beneficial not only on the individual levels but also to the country. For instance, gender equality in sports can create economic opportunities, thereby creating an enabling environment for economic growth in the country at large.

\section{References}

Acar, F., Altunok, G. (2013). The "politics of intimate" at the intersection of neoliberalism and neo-conservatism in contemporary Turkey. Women's Studies International Forum, 41, 14-23.

Ahmad, R.H. (2015). Women sports in India-constraints, challenges, complications, and its remedies. International Journal of Applied Research, 1 (13), 656-659.

Asayesh, L., Karkon, H., Karkon, M., Shabani, A. (2013). The challenges of athletics in Iran: A Delphi study. European Journal of Experimental Biology, 3 (6), 66-72.

Arslan, B., Koca, C. (2007). A content analysis of Turkish daily newspapers regarding sportswomen and gender stereotypes. Annals of Leisure Research, 10 (3), 310-327

Ayvazoglu, N.R. (2017). The coverage of female athletes at London 2012 summer games in Turkish sports media. The Anthropologist, $27(1-3), 49-57$.

Ballantyne, K.N., Kayser, M., Grootegoed, J.A. (2012). Sex and gender issues in competitive sports: An investigation of a historical case leads to a new viewpoint, British Journal of Sports Medicine, 46 (8), 614-617.

Bibi, I., Khan, S., Khan, W. (2016). Influence of socio-cultural problems on sports participation: A case of female elite athletes in Pakistan. International Journal of Scientific and Engineering Research, 7 (6).

Brien, O., Lloyd., K., Riot, C. (2017). Exploring the emotional geography of the leisure-time physical activity space with mothers of young children. Leisure Studies, 36 (2), 220-230.

Bruce, T., Hovden, J., Markula, P. (eds.). (2010). Sportswomen at the Olympics: A global comparison of newspaper coverage. Rotterdam: Sense Publishers.

Bruce, T. Scott-Chapman, S. (2010). New Zealand: Intersections of nationalism and gender in Olympics newspaper coverage.

Bruce, T. (2013). Reflections on communication and sport: On women and femininities. Communication and Sport, 1, 125-137.

Bruce, T. (2015). Assessing the Sociology of Sport: On Media and Representations of Sportswomen. International Review for the Sociology of Sport, 50 (4-5), 380-384.

Bruce, T. (2015). New Rules for New Times: Sportswomen and Media Representation in the Third Wave, Sex Roles. Springer Science Business Media New York.

Burton, L.J. (2015). Underrepresentation of women in sport leadership: A review of research. Sport Management Review, 18, $155-165$.

Buytendijk, F.J.J. (1953). Das Fußballspiel: Eine psychologische Studies. Würzburg: Werkbund-Verlag.

Chien, Y.C. (2013). The application of IPA to examine the needs on exercise environment among the middle-aged and elder residents. Master's Thesis, National Pingtung University of Science and Technology, Pingtung, Taiwan.

Cleland, J. (2014). Racism, football fans, and online message boards: How social media has added a new dimension to racist discourse in English football. Journal of Sport and Social Issues, 38 (5), 415-431. 
Fahmy, M. (2011). Increased participation and competitions: 5th FIFA Women's Football Symposium. Frankfurt: Federation International de Football Association.

Feldman, D.E., Barnette, T., Shrier, I., Abenhaim, L. (2003). Is physical activity differentially associated with different types of sedentary pursuits? Archives of Pediatrics and Adolescent Medicine, 157 (8), 797-802.

FIFA (2015). FIFA, football and women; why reform must specify inclusion and investment, submitted to Mr Francias Carrard, Chair of FIFA Reform Committee, October, 2015. Retrieved from: https://img.fifa.com/image/upload/i2berd89n7syxdjl5fhq.pdf (16.12.2019).

Fitzgibbons, R.P. (2015). Sports and the Catholic family. Retrieved from: http://www.maritalhealing.com/conflicts/sportsandfamily.php (16.12.2019).

Forbes (2016). The world's highest paid atheletes. Retrieved from: https://www.forbes.com/athletes/\#3cc9b30b55ae (15.12.2019).

Gorman, P.P., Butler, R.J., Rauh, M.J., Kiesel, K., Plisky, P.J. (2012). Differences in dynamic balance scores in one sport versus multiple sport high school athletes. International journal of sports physical therapy, 7 (2), 148-153.

Hacettepe University Institute of Population Studies (2019). 2018 Turkey Demographic and Health Survey. Hacettepe University Institute of Population Studies, T.R. Presidency of Turkey Directorate of Strategy and Budget and TÜBITAK, Ankara, Turkey.

Hardin, M., Croston, A. (2012). The influence of gender-role socialization, media use, and sports participation on perception of gender appropriate sports. Journal of Sport Behavior, 32, 207-226.

Huang, H.C., Liu, L.W., Chang, C.M., Hsieh, H.H., Lu, H.C. (2019). The effects of locus of control, agents of socialization, and sports socialization situations on women's sports participation in Taiwan. International Journal of Environmental and Public Health, 16, $18-41$.

Huffington Post (2016). Women, media bias and the olympics. Retrieved from: https://www.huffingtonpost.com/samantha_levine-/ women-media-bias-and-the-_b_11459540.html (18.12.2019).

Hurriyet Daily News (2018). Violence is the biggest problem women face in Turkey: Poll In Hurriyet Daily News. Retrieved from: http:/l www.hurriyetdailynews.com/violence-is-the-biggest-problem-women-face-in-turkey-poll-128372 (16.12.2019).

Jabeen, A., Marwar, K.M., Khan, A., Ali, K. (2017). Issues and challenges for female participation in physical activities at secondary school level in Sargodha division.

Jacobs, J. (2017). Why Do not Women Coach Men? Lawson, Geno Others At FinaL Four Say They Should. Hartford Courant. Retrieved from: https://www.courant.com/sports/hc-jacobs-column-women-coaches-0331-20170330-column.html.

Johnson, B.A., Salzberg, C.L., Stevenson, D.A. (2011). A systematic review: plyometric training programs for young children. J Strength Cond Res, 25, 2623-3263.

Jones, D. (2013). Online coverage of the 2008 Olympic games on the ABC, BBC, CBC and TVNZ. Pacific Journalism Review, 19 (1), 244-263.

Kagnicioglu, D. (2017). The role of women in working life in Turkey. WIT Transactions on Ecology and The Environment, 226, 349-358.

Kane, G., Alavi, M., Labianca, G., Borgatti, S. (2014). What's Different about Social Media Networks? A Framework and Research Agenda. MIS Q, 38, 274-304.

Kanters, M.A., Bocarro, J., Casper, J. (2015). Supported or pressured? An examination of agreement among parents and children on a parent's role in youth sports. Journal of Sport Behavior, 31 (1), 64-80.

Kara, F., Demirci, A. (2010). An assessment of outdoor recreational behaviors and preferences of the residents in Istanbul. Scientific research and essays, 5 (1), 93-104.

Khalaf, S.B.H. (2014) Arabic women's participation in sport: barriers and motivation among Egyptian and Kuwaiti athletes. Doctoral Dissertation. University of Wales.

Khan, Y.M., Jamil, A., Khan, U.A., Kareem, U., Imran, G. (2012). Female students' opinion about women's participation in sports. International Journal of Academic Research in Business and Social Sciences, 2 (9), 275-283.

Kian, E.M., Bernstein, A., McGuire, J.S. (2013). A major boost for gender equality or more of the same? The television coverage of female athletes at the 2012 London Olympic Games. Journal of Popular Television, 1, 143-149. DOI: 10.1386/jptv.1.1.143_1.

Knoppers, A., McDonald, M. (2010). Scholarship on gender and sport in Sex Roles and beyond. Sex Roles, 63, 311-323. DOI: 10.1007/ s11199-010-9841-z.

Koca, C., Hacısoftaoğlu, I. (2010). Sport participation of women and girls in modern Turkey. In: T. Benn, G. Pfister, H. Jawad (4 $4^{\text {th }}$ eds.). Muslim women in sport. United Kingdom: Routledge. 
Koca, C., Hacısoftaoğlu, I. (2011). Struggling for empowerment sport participation of women and girls in Turkey. In: T. Benn, G. Pfister, H. Jawad (4th eds.), Muslim women in sport (pp. 154-166). London: Routledge.

LaVoi, N., Kane, M.J. (2011). Sociological aspects of sport. In: P.M. Pederson, J.B. Parks, J. Quarterman, L. Thibault (4th eds.), Contemporary Sport Management (pp. 374-391). Champaign, IL: Human Kinetics.

Leigh, K. (2012). Turkey's female athletes, like women nationwide, reap rewards. New York Times. Retrieved from: https://www.nytimes. com/2012/09/09/sports/olympics/in-turkey-female-athletes-have-come-a-long-way.html (16.12.2019).

Lin, T.E., Liu, C.C., Lee, C.H., Tsai, F.H., Chen, Z.M., Lee, S.Y. (2012). A study of socialization into sport and motivations of athletes' participation sport. National Pingtung University of Education, 15, 394-406.

MacIntosh, E.W., Nicol, L. (2012). Athletes' event experiences of the XIX Commonwealth Games in Delhi, India. International Journal of Event and Festival Management, 3 (1), 12-29.

Marwat, M.K., Zia-ul-Islam, S., Waseem, M., Khattak, H., BiBi, S. (2014). Sport performance of Muslim women and different constraints in their way to participation in sport. International Journal of Humanities and Social Science, 4 (10), 208-214.

Meân, L.J. (2014). Sport websites, embedded discursive action, and the gendered reproduction of sport. In: A.C. Billings, M. Hardin (eds.), Routledge handbook of sport and new media (pp. 331-341). New York: Routledge.

Monster Salary Index (2017). Women of India, Monster Salary Index (MSI) report on gender pay parity. Retrieved from: http://media. monsterindia.com (8.12.2017).

Moran, R. (2014). Cultural influences that affect participation in sports act. Retrieved from: https://prezi.com/x7aybvzgpdve/ cultural-influences-that-affect-participation-in-sports-act.

Moradi, B., Yoder, J.D. (2011). The psychology of women. In: E.M. Altmaier, J.C. Hansen (eds.), The Oxford Handbook of Counseling Psychology (pp. 346-374). New York: Oxford Press.

Müftüler-Baç, M. (2012). Gender equality in Turkey. Retrieved from: http://research.sabanciuniv.edu/18894/1/20120207ATT37506EN. pdf.

Nogueira, A., Molinero, O., Salguero del Valle, A., Lucidi, F., Marquez, S. (2017). Identification of gender discrimination in sports: Training of agents of change, Revista de Psicología del Deporte/Journal of Sport Psychology, 27 (3), 43-49.

Öztürk, P., Koca, C. (2019). Generational analysis of leisure time physical activity participation ofwomen in Turkey. Leisure Studies, 38 (2), 232-244.

Pavlidis, A., Fullagar, S. (2016). Sport, gender, and power. Oxford: Routledge.

Pelak, C.F. (2005). Negotiating gender/race/class constraints in the new South Africa a case study of women's soccer. International Review for the Sociology of Sport, 40 (1), 53-70.

Pfister, G., Hacısoftaoğlu, I. (2016). Women's Sport as a Symbol of Modernity: A Case Study in Turkey. The International Journal of the History of Sport, 33 (13), 1470-1482.

Ponseti, F.X., Borrás, P.A., Cantallops, J., García-Mas, A. (2017). Fair play, cheating and gamesmanship in grassroots sports. En Proceedings ISSP 14th World Congress Sport Psychology, Sevilla (349). Madrid: Dykinson.

Ruseski, J.E., Humphreys, B.R., Hallmann, K. (2011) Family structure, time constraints, and sport participation. European Review Aging and Physical Activity, 8, 57-66.

Saavedra, E., Martha, B. (2010). Women, sport and development. International Platform on Sport and Development, 1, 23-30.

Sailors, P., Teetzel, S., Weaving, C. (2012). No Net Gain: A Critique of Media Representations of Women's Olympic Beach Volleyball. Feminist Media Studies, 12 (3), 468-472.

Scott, D., Mowen, A.J. (2010). Alleviating park visitation constraints through agency facilitation strategies. Journal of leisure research, $42(4), 535-550$.

Spaaij, R., Anderson, A. (2012). Parents or peers: Which is it? Sport socialization and team identification in Australia: A rejoinder to Melnick and Wann. International Review of Sociology, 47, 526-530.

Stanis, S.A.W., Schneider, I.E., Pereira, M.A. (2010). Parks and health: Differences in constraints and negotiation strategies for parkbased leisure-time physical activity by stage of change. Journal of physical activity and health, 7, 273-284.

Story, C., Markula, P. (2017). I had one year in junior, and then I was too old: structural age rules and the girlification in Canadian elite women's figure skating. Sport in society, 20 (9), 1223-1240.

Tansel, A., Dalgic, B., Guven, A. (2014). Wage inequality and wage mobility in Turkey. Discussion paper IZA DP No. 8669. Retrieved from: http://ftp.iza.org/dp8669.pdf (15.12.2019). 
Taylor, A.C., Schweichler, J.T., Jorgensen, B.L., McKown, E.H., Teresak, M. (2014). Parental support behaviors for children participating in community soccer programs. The Sport Journal. Retrieved from: http://thesportjournal.org/article/parental-support-behaviorsfor-children-participating-in-community-soccer-programs (15.12.2019).

Tekin, A. (2010). The influence of religious and socio-cultural variables on the participation of female university students in leisure activities. World applied sciences journal, 9 (11), 1286-1293.

Toksöz, G. (2012). The state of female labor in the impasse of the neoliberal market and patriarchal family. In: S. Dedeoğlu, A.Y. Elveren (eds.), Gender and society in Turkey: The impact of neoliberal policies, political Islam and EU accession (pp. 47-64). New York: I.B. Tauris.

Trolan, E.J. (2013). The media's impact on gender inequality within the sport. Procedia Social and Behavioral Sciences, 91, $215-227$.

TÜIK (2012b). İsgücü İstatistikleri. Retrieved from: http://www.tuik.gov.tr (16.12.2019).

UNESCO (2015). International Charter of Physical Education, Physical Activity and Sport. UNESCO.

Velázquez, P. (2017). Sports values: A European perspective. En Proceedings ISSP 14th World Congress Sport Psychology, Sevilla (212). Madrid: Dykinson.

Wagner, M.M. (2016). The Decline of Women's Rights in Turkey: Political Islam... or Tayyip. Undergraduate Honors thesis. Retrieved from: https://scholar.colorado.edu/cgi/viewcontent.cgi?article=2383\&context=honr_theses (16.12.2019).

Walker, N.A., Bopp, T. (2010). The Underrepresentation of Women in the Male-Dominated Sport Workplace: Perspectives of Female Coaches. Workplace Rights, 15 (1), 47-64.

Wangari, G., Kimani, E., Wango, G. (2017). Challenges faced by women football players who participate in Football Leagues. Journal of Developing Country Studies, 2 (1), 13-35.

Westcott, L., Foley-Fellow, J.W. (2018). World Cup harassment highlights issues female sports journalists face daily in CPJ. Retrieved from: https://cpj.org/blog/2018/07/world-cup-harassment-highlights-issues-female-spor.php (15.12.2019).

Zhang, T., Solmon, M.A., Gao, Z., Kosma, M. (2012). Promoting school students' physical activity: A social ecological perspective. Journal of Applied Sport Psychology, 5 (1), 92-105.

Cite this article aS: Yenilmez, M.I. (2021). Gender Inequality and Female Sports Participation in Turkey. Central European Journal of Sport Sciences and Medicine, 1 (33), 27-41. DOI: 10.18276/cej.2021.1-03. 